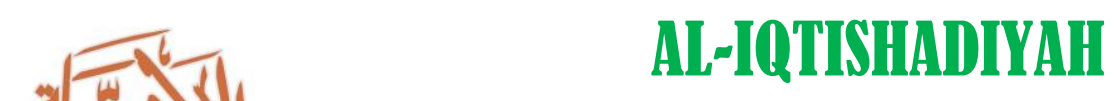

Jurnal Ekonomi Syariah dan Hukum Ekonomi Syariah

E-ISSN: 2621-0274; P-ISSN: 2442-2282

Volume 6, Nomor 2, Desember 2020

\title{
PENGEMBANGAN UMKM MELALUI FINTECH SYARIAH DI TENGAH WABAH COVID-19
}

\section{Trimulato}

Fakultas Ekonomi dan Bisnis Islam Universitas Islam Negeri Alauddin Makassar, Indonesia. E-mail: tri.mulato@uin-alauddin.ac.id

\section{ARTICLE INFO}

Keywords:

Covid-19 Pandemic;

Sharia Fintech; SMEs

Kata Kunci:

Fintech Syariah; Pandemi Covid-19; UMKM

\section{ABSTRACT}

The impact of the Covid-19 outbreak made some business activities experienced retarding. It is required that other institutions can support the development of SMES amid the Covid-19 outbreak, one of which is the sharia fintech. The purpose of this research is to know the development of Sharia fintech and to know the pattern of development of SMES through Sharia fintech. This research is a library research, which is by taking some previously presented sources related to sharia and SMEs. The nature of the research is qualitative with the secondary data source of pre-existing data. This research data analysis technique is qualitative descriptive, by describing the development of Sharia fintech and the development pattern of SMEs through Sharia fintech. The results showed that the current Sharia fintech assets reached 50.591.727.786 rupiah, or experienced a growth of 8.32 percent compared to the period of February 2020. Of the 13 sharia fintechs there are 6 Sharia fintech companies that focus on financing for SMEs. The pattern of SMEs development through sharia fintech can be done by adding the role of fintech, not merely giving from finance but also can be a companion in business development in particular about the marketing products of SMEs. Sharia fintech can facilitate space to sell products through online by using the marketplace and websait owned by Sharia fintech.

\section{ABSTRAK}

Dampak dari wabah covid-19 membuat beberapa kegiatan bisnis mengalami perlambatan. Diperlukan lembaga lain yang dapat mendukung perkembangan UMKM di tengah wabah covid-19, salah satunya adalah fintech syariah. Tujuan dari penelitian ini adalah untuk mengetahui perkembangan dari fintech syariah dan mengetahui pola pengembangan UMKM melalui fintech syariah. Penelitian ini adalah penelitian studi pustaka, yaitu dengan mengambil beberapa sumber yang telah disajikan sebelumnya terkait fintech syariah dan UMKM. Sifat penelitian yaitu kualitatif dengan sumber data sekunder dari datadata yang telah ada sebelumnya. Teknik analisis data penelitian ini deskriptif kualitatif, dengan menguraikan perkembangan dari fintech syariah dan pola pengembangan UMKM melalui fintech syariah. Hasil penelitian menunjukkan bahwa tota aset fintech syariah saat ini mencapai 50.591.727.786 rupiah, atau mengalami pertumbuhan 8,32 persen jika dibandingkan pada periode februari 2020. Dari 13 fintech syariah ada 6 perusahaan fintech syariah yang fokus pada pembiayaan 
untuk UMKM. Pola pengembangan UMKM melalui fintech syariah dapat dilakukan dengan menambah peran dari lembaga fintech, tidak sekedar memberikan dari keuangan tetapi juga dapat menjadi pendamping dalam pengembangan bisnis khususnya tentang pemasaran produk UMKM. Fintech syariah dapat memfasilitasi ruang untuk menjual produk melalui online dengan memafaatkan marketplace dan websait yang dimiliki fintech syariah.

\section{Pendahuluan}

Indonesia sebagai negara dengan penduduk muslim terbesar di dunia. Idealnya memiliki peluang besar untuk menjadi tempat pengembangan produk halal termasuk pemikiran-pemikiran ekonomi Islam. Dengan jumlah penduduk yang besar, Indonesia dapat menjadi laboraturium bagi pengembangan keilmuan ekonomi Islam. Namun hal ini dapat terwujud jika Islam sudah menjai way of life termasuk keputusan-keputusan dalam bidang ekonomi. Melihat potensi produk dan jasa halal di dunia, maka potensi bisnis syariah di Indonesia masih sangat besar, melihat banyaknya potensi yang tergarap dengan baik. Untuk itu Indonesia masih perlu untuk lebih meningkatkan pemahaman dan kesadaran akan produk dan jasa halal maupun gaya hidup halal di lingkungan pemerintah. ${ }^{1}$

Perbankan syariah melakukan segala kegiatan bisnisnya patuh pada prinsip syariah, juga sesuai demokrasi ekonomi, kemudian juga menerapkan prinsip kehati-hatian. Bank syariah dapat berkontribusi bagi pembangunan nasional agar tercipta keadilan, adanya kebersamaan, serta pemerataan kesejahteraan bagi seluruh rakyat. Sistem pengelolaan lembaga keuangan syariah tidak sama dengan mengelola lembaga keuangan konvensional. Jika disamkan pengelolaannya tentu akan menimbulkan kesulitan karena secara prinsip sudah berbeda. Perlu dipahami bahwa saat ini sebagian besar pengelola lembaga keuangan syariah berasal masih berasal dari bank konvensional sehingga mempersulit pengembangannya. Masih banyak yang sulit melepaskan diri dari tradisi bank konvensional yang sudah sangat melekat. Lebih luas lagi, masyarakat kita memang sudah terbiasa dengan pelayanan bank konvensional dan belum terbiasa dengan layanan bank syariah. Bank konvensional sudah eksis di bumi Indonesia sudah sangat lama, hadir sejak berdirinya De Javache Bank 1872. Sedangkan kemunculan lembaga keuangan syariah masih diangggap baru, kehadirannya masih seperti makhluk asing, kegiatan operasionalnya masih sulit diterima akal banyak kalangan. Sikap masyarakat yang seperti ini juga ikut memberi pengaruh bagi pengelola lembaga keuangan syariah. Lembaga keuangan syariah harus dimulai dari pemahaman kita secara mendalam tentang kemudharatan sistem bunga, falsafah lembaga keuangan syariah, dan dampaknya secara luas terhadap kehidupan masyarakat dalam relevansinya dengan pembangunan ekonomi. Bank syariah dengan sistem bagi hasil dirancang untuk terbinanya kebersamaan dan kemitraan dalam menanggung risiko usaha dan berbagi hasil usaha antara: pemilik dana atau pemodal (shahibul maal) yang menyimpan uangnya di lembaga keuangan

\footnotetext{
${ }^{1}$ Sofyan, Riyanto. Bisnis Syariah Mengapa Tidak ? (Jakarta: PT Gramedia Pustaka Utama. 2011)
} 
syariah. Lembaga keuangan syariah selaku penegelola dana yang terkumpul (mudharib), dan masyarakat umum yang membutuhkan dana bisa berstatus peminjam dana atau pengelola usaha sebagai mitra usaha. ${ }^{2}$

Segala jenis usaha dapat dikembangkan melalui bank syariah, dalam hal ini berupa penyaluran pembiayaan. Jenis pembiayaan yang dimiliki oleh bank syariah yaitu pembiayaan dengan skema bagi hasil, skema sewa, dan skema jual beli. Ketiga skema pembiayaan ini dapat dilakukan oleh perbankan syariah dalam penyaluran pembiayaan untuk pengembangan usaha. Sebagaimana mana salah satu tujuan dari hadirnya perbankan syariah ikut serta dalam meningkatkan perekonomian negara ini. Meskipun bank syariah masih terhitung masih mudah jika dibandingkan dengan konvensional, bank syariah tetap mampu bersaing untuk berkontribusi untuk meningkatkan perekonomian bangsa. Bank syariah yang berfungsi untuk menghimpunan dana bagi masyarakat dan menyalurkan kembali ke masyarakat dalam bentuk pembiayaan. Penyaluran pembiayaan ini diharapkan bisa memberikan solusi bagi masyarakat yang membutuhkan dana, khususnya untuk kegiatan yang bersifat produkif. Misalnya ada masyarakat yang hendak mengembangkan usahanya, namun terbatas dengan masalah dana atau modal, bank syariah dapat hadir untuk memberikan pembiayaan. Dengan skema pembiayaan yang dimiliki oleh bank syariah yang berbeda dengan skema kredit yang dimiliki oleh bank syariah. Begitupun ketentuan jenis usaha atau objek pembiayaan yang harus memenuhi prinsip syariah. Untuk segala jenis usaha temasuk usaha, mikro, kecil dan menangah (UMKM). Hanya saja sepertinya penyaluran pembiayaan bank syariah untuk kegiatan produk khususnya untuk UMKM belum menjadi prioritas. Pembiayaan di bank syariah masih di dominasi oleh kegiatan konsumtif. Berdasarkan statistik perbankan syariah yang dikeluarkan oleh Otoritas Jasa Keuangan, sebagai berikut;

Tabel 1. Penyaluran Pembiayaan di Bank Syariah

\begin{tabular}{|c|c|c|c|c|}
\hline No & Jenis Bank Syariah & Jenis Pembiayaan & Bulan Maret 2020 & Kontribusi (\%) \\
\hline \multirow[t]{7}{*}{1} & Bank Umum & Modal Kerja & & \\
\hline & Syariah (BUS) & a. UMKM & a. 37.475 & a. 16,40 \\
\hline & & $\begin{array}{l}\text { b. Non UMKM } \\
\text { Investasi }\end{array}$ & b. 42.069 & b. 18,42 \\
\hline & & a. UMKM & a. 23.930 & a. 10,48 \\
\hline & & $\begin{array}{l}\text { b. Non UMKM } \\
\text { Konsumsi }\end{array}$ & b. 29.023 & b. 12,71 \\
\hline & & a. Non UMKM & a. 95.897 & a. 41,99 \\
\hline & & Jumlah & 228.394 & 100 \\
\hline
\end{tabular}

\begin{tabular}{|c|c|c|c|c|}
\hline \multirow[t]{4}{*}{2} & Unit Usaha & Modal Kerja & & \\
\hline & Syariah (UUS) & $\begin{array}{l}\text { a. UMKM } \\
\text { b. Non UMKM } \\
\text { Investasi }\end{array}$ & $\begin{array}{ll}\text { a. } & 8.741 \\
\text { b. } & 22.879\end{array}$ & $\begin{array}{l}\text { a. } 6,56 \\
\text { b. } 17,17\end{array}$ \\
\hline & & a. UMKM & a. 5.043 & a. 3,78 \\
\hline & & b. Non UMKM & b. 29.219 & b. 21,93 \\
\hline
\end{tabular}




\begin{tabular}{|c|c|c|c|c|}
\hline & & \multicolumn{3}{|l|}{ Konsumsi } \\
\hline & & a. Non UMKM & a. 67.375 & a. 50,56 \\
\hline & & Jumlah & 133.257 & 100 \\
\hline \multirow[t]{4}{*}{3} & Bank Pembiayaan & & & \\
\hline & \multirow{3}{*}{$\begin{array}{l}\text { Rakyat Syariah } \\
\text { (BPRS) }\end{array}$} & a. UMKM & a. $6.108,146$ & a. 57,20 \\
\hline & & b. Non UMKM & b. $\quad 4.570,175$ & b. 42,80 \\
\hline & & Jumlah & $10.678,321$ & 100 \\
\hline 4 & Total & & $372.329,32$ & 100 \\
\hline
\end{tabular}

Sumber : Otoritas Jasa Keuangan (OJK) Statistik Perbankan Syariah Maret 2020 (Data diolah)

Dari data diatas menunjukkan penyaluran pembiayaan yang ada di bank syariah. Secara jenis bank syariah ada tiga jenis, yaitu Bank Umum Syariah (BUS), Unit Usaha Syariah (UUS), dan Bank Pembiayaan Rakyat Syariah (BPRS). Bentuk peruntukan penyaluran pembiayaan di bank syariah juga terdiri dari tiga yaitu untuk kegiatan konsumsi, modal kerja dan investasi. Kemudian peruntukan penyaluran pembiayaan tersebut dibagi dua yaitu pada pembiayaan sektor UMKM dan Non-UMKM. Data diatas menunjukkan bahwa penyaluran pembiayaan di bank syariah masih di dominasi oleh kegiatan konsumtif (bukan produktif) jelas bukan untuk UMKM. Pada BUS porsi pembiayaan konsumtif mencapai 41,99 persen, selebihnya untuk modal kerja dan investasi. Itupun bukan untuk UMKM yang dominan. Berbeda dengan posisi BPRS yang penyaluran pembiayaan nya lebih besar untuk UMKM yaitu mencapai 57, 20 persen, selebihnya untuk non UMKM. Hanya saja perlu diperhatikan bahwa kontribusi penyaluran pembiayaan BPRS secara kesuluruhan hanya memberi porsi 2,28 persen dari total pembiayaan di Bank Syariah. Hal ini menunjukkan bahwa perlu ada evaluasi dan koreksi bagaimana peran perbankan syariah untuk berkontribusi pada perekonomian negara jika pembiayaan masih selalu didominasi pada kegiatan konsumtif bukan hal-hal produktif termasuk UMKM.

Perlu ada keberanian, dan keseriusan dari bank syariah untuk meningkatkan volume pembiayaan bank syariah untuk kegiatan produktif khususnya untuk UMKM. Apalagi saat ini negara kita sedang diuji dengan lesunya perekonomian, daya beli masyarakat yang sangat menurun, kegiatan ekonomi yang lamban, yang pastinya membutuhkan stimulus dan perhatian bagi semua para pelaku ekonomi termasuk bank syariah akibat munculnya wabah virus corona (covid-19). Perlu dipikirkan dan dicari jalan keluarnya, agar bagaimana bank syariah tetap dapat mencapai tujuannya yaitu berkontribusi dalam perekonomian. Ditengah wabah ini, banyak sektor yang tergerus dan menurun termasuk perbankan syariah dan pelaku UMKM.

Untuk menekan dampak covid-19 terhadap kegiatan perbankan, termasuk perbankan syariah, maka Otoritas Jasa Keuangan (OJK), telah mengeluarkan beberapa aturan-aturan. POJK No. 18/POJK.03/2020 Tentang Perintah Tertulis Untuk Penanganan Permasalahan Bank POJK ini mengamanatkan OJK untuk mengambil langkah-langkah yang diperlukan untuk menjaga stabilitas sistem keuangan khususnya di sektor perbankan di tengah ancaman pelemahan ekonomi sebagai dampak penyebaran pandemik virus COVID-19. POJK ini secara umum terdiri dari: 5 Ruang lingkup pengaturan berlaku bagi Bank yaitu Bank Umum Konvensional (BUK), Bank Umum Syariah (BUS), Bank Perkreditan Rakyat (BPR), Bank Pembiayaan Rakyat 
Syariah (BPRS), dan kantor cabang dari bank yang berkedudukan di luar negeri. Perintah Tertulis diberikan kepada Bank yang memenuhi kriteria berdasarkan penilaian OJK. Kewenangan OJK memberikan Perintah Tertulis kepada Bank untuk: Melakukan penggabungan, peleburan, pengambilalihan, dan/atau integrasi; dan/atau Menerima penggabungan, peleburan, pengambilalihan dan/ atau integrasi. Kewajiban kepada Bank yang diberikan Perintah Tertulis untuk menyusun rencana tindak, serta melaksanakan dan menjaga kelancaran proses penggabungan, peleburan, pengambilalihan, dan/atau integrasi sesuai dengan rencana tindak. ${ }^{3}$

Dalam kondisi di tengah wabah covid-19, pihak lain yang juga terkena dampak selain bank syariah yaitu pelaku UMKM. Segmen UMKM mengalami penurunan pendapatan akibat tingkat penjualan semenjak munculnya wabah virus corona (covid-19) yang belum berakhir ini. Para pelaku UMKM adalah pelaku usaha produktif yang digerakakkan baik dari secara perorangan maupun dalam bentuk badan usaha telah memenuhi kriteria yang telah ditentukan dan diklasifikasikan berdasarkan undang-undang tentang UMKM nomor 20 tahun 2008 tercatat sebagai jenis usaha mikro, misalnya usaha kuliner, konveksi, dan bisnis lainnya. Perkembangan para pelaku UMKM mencapai 99,9 persen dari total unit usaha yang ada di Indonesia menjadi dominasi dari seluruh usaha yang ada. Jumlah unit usaha UMKM yang tersebar di seluruh Indonesia mencapai 62,9 juta unit usaha meliputi usaha perdagangan, usaha pertanian, usaha perternakan, usaha dibidang kehutanan, usaha dibidang perikanan, usaha pertambangan, usaha pengolahan bangunan, komunikasi, hotel, restoran dan berbagai jenis usaha lainnya. Perkembangan sektor UMKM di Indonesia didorong dari banyak faktor antaranya, adanya pemanfaatan sarana dan penggunaan teknologi terus berkembang, informasi yang mendukung diakses lebih cepat, serta terjalinnya komunikasi yang lebih aktif, pemberian kemudahan peminjaman modal usaha bagi sektor produktif, menurunnya pajak PPH final. Dengan pertumbuhan yang demikian masih dinilai perlu adanya percepatan karena beberapa faktor, sehingga lebih efektif, bupaya dilakukan lebih baik kedepannya.termasuk pada bagian perpajakan usaha yang sulit dipenuhi seharusnya tidak memberatkan. Ditengah perkembangan UMKM di awal tahun 2020 belum maksimal mengakibatkan perkembangannya cenderung melambat. Kondisi UMKM di Indonesia kembali di uji dengan munculnya wabah covid-19 ditengah masyarakat Indonesia. UMKM menjadi salah yang terkena dampak yang cukup buruk, sehingga membutuhkan dorongan berbagai pihak untuk pemulihannya. Agar UMKM dapat berkembang lebih baik lagi. ${ }^{4}$

Unit Usaha mikro kecil menengah (UMKM) menjadi salah satu sektor yang terdampak cukup hebat akibat pandemi covid-19 di Indonesia. Menteri Koperasi dan Usaha Kecil dan Menengah RI, Teten Masduki, menyebutkan bahwa hal ini disebabkan karena usaha UKM bersifat harian dan banyak mengandalkan interaksi

\footnotetext{
${ }^{3}$ Dikutip dari https://www.ojk.go.id/id/berita-dan-kegiatan/siaran-pers/Pages/Siaran-Pers-OJKKeluarkan-Paket-Kebijakan-Lanjutan-Stimulus-Covid-19-.aspx, 11 Juli 2020.

${ }^{4}$ Dikutip dari https://www.kompasiana.com/maretaintansari/5ebc0b27d541df248350fec2/pengaruhcovid-19-terhapad-pertumbuhan-umkm-di-indonesia, pada tanggal 10 Juli 2020.
} 
langsung, sehingga adanya pembatasan PSBB dan social distancing tentu saja membuat permintaan turun drastis. ${ }^{5}$ Pandemi corona atau disebut Corona Virus Disease 2019 (Covid-19) begitu sangat terasa memberi dampak buruk bagi perekonomian dalam negeri, dari banyak banyak aspek terutama dari sisi konsumsi, korporasi yang melambat, sektor keuangan yang terganggu, dan kegitan bisnis para pelaku Usaha Mikro Kecil Menengah (UMKM). Hasil kajian dari Kementerian Keuangan menyebutkan bahwa wabah covid-19 menimbulkan ancaman kehilangan pendapatan suatu rumah tangga, penyebab tidak dapat bekerja mengakibatkan sulitnya terpenuhi kebutuhan. Terlebih bagi masyarakat yang masuk kategori miskin dan rentan serta bagi kategori sektor informal. Adanya penurunan daya beli di tengah masyarakat semakin banyak. Adapun bagi korporasi, pelemahan perekonomian akibat virus corona membuat aktifitas berbagai sektor seperti manufaktur, kegiatan perdagangan, jasa transportasi, dan sektor akomodasi termasuk usaha restoran dan perhotelan menjadi pihak paling rentan terkena dampak covid-19. Sehingga mengakibatkan adanya gangguan aktifitas bisnis yang akan menurun kinerjanya, terjadilah pilihan pemutusan hubungan kerja, dan dampak paling buruk mengalami ancaman kebangkrutan. Disamping itu, akibat memburuknya aktifitas ekonomi dan dunia usaha akan merembet ke sektor keuangan karena adanya kesulitan pembayaran dari pelaku usaha yang memiliki kewajiban pembayaran. Perbankan dan perusahaan pembiayaan dihadapkan pada persoalan kesulitan likuiditas dan insolvency. Selanjutnya, ancaman depresiasi rupiah, volatilitas pasar keuangan, dan capital flight. Kemenkeu mengkaji dampak Covid-19 membuat UMKM tidak dapat melakukan usahanya sehingga terganggu kemampuan memenuhi kebutuhan kredit. ${ }^{6}$

Pandemi Covid-19 telah memberikan dampak terhadap berbagai sektor usaha termasuk UMKM. Pada tataran ekonomi global, wabah covid-19 memberikan dampak perlambatan yang sangat signifikan pada perekonomian domestik di banyak negara, termasuk dampak bagi keberadaan UMKM. Laporan Organisation for Economic Co-operation and Development (OECD) menyebutkan bahwa pandemi dapat menjadi ancaman krisis ekonomi besar, akibat terhentinya aktivitas produksi di banyak negara, membuat rendahnya tingkat konsumsi masyarakat. Tidak ada satupun negara mampu memprediksi kapan pandemi akan berakhir. Cara sederhana yang dapat dilakuka untuk dapat bertahan di tengah pandemi adalah dengan mempersiapkan langkah dan strategi yang tepat, kemudian menyusun strategi tersebut baik untuk jangka pendek maupun jangka panjang. Agar dapat bertahan sambil terus berharap agar vaksin virus ini covid-19 dapat segera ditemukan dan diproduksi massal, agar kondisi lebih baik. Kebijakan jangka pendek yang dapat ditempuh dengan pemberian bantuan keuangan dalam bentuk pinjaman lunak, yang disesuaikan kondisi pelaku usaha atau bantuan tunai langsung baik dari pemerintah

\footnotetext{
${ }^{5}$ Dikutip dari https://www.cnbcindonesia.com/news/20200429173402-8-155339/ini-kata-tetenmasduki-soal-dampak-covid-19-bagi-umkm, pada tanggal 10 Juli 2020.

${ }^{6}$ Dikutip dari https://nasional.kontan.co.id/news/menghitung-dampak-covid-19-terhadap-duniausaha-hingga-umkm, pada tanggal 11 Juli 2020.
} 
maupun sektor swasta. Kemudian untuk strategi jangka panjang difokuskan pada pengenalan dan pelatihan untuk penggunaan teknologi digital bagi UMKM untuk meningkatkan pendapatan. Sekaligus persiapan untuk memasuki era Industri 4.0 sebagai respon bagi perkembangan teknologi yang ada saat ini, termasuk pelatihan teknologi bidang pemasaran dan pengenalan produk-produk UMKM sehingga akan dikenal lebih luas. ${ }^{7}$

Pandemic covid-19 memberi berdampak pada ketidakstabilan dalam perekonomian terutama pada UMKM. Pelaku UMKM ini merasakan dampak langsung berupa penurunan omset penjualan dikarenakan adanya himbauan pemerintah dan penerapan PSBB yang menghimbau masyarakat untuk tetap dirumah sehingga cukup banyak UMKM yang harus berenti beroperasi untuk sementara waktu.Untuk itu pelaku UMKM harus memiliki strategi untuk dapat bertahan di tengah pandemikini dan dituntut untuk dapat menyesuaikan diri terhadap kondisi yang terjadi. Beberapa strategi bertahan yang di rekomendasikan yang dapat di lakukan UMKM untuk dapat mempertahankan bisnisnya, yaitu (1) melakukan penjualan melalui e-commercekarena masyarakat sekarang banyak beralih ke belanja online. (2) Melakukan pemasaran produk dengan memanfaatkan teknologi digital (digital marketing) untuk dapat menjangkau lebih banyak konsumen. (3) melakukan perbaikan kualitas produk dan kualitas serta jenis layanan. (4). Melakukan pemasaran hubungan pelanggan (customer relationship marketing) untuk menciptakan kepercayaan konsumen dan menumbuhkan loyalitas pelanggan. ${ }^{8}$

Perlu upaya yang strategis dalam mengembangkan UMKM yang tergerus akibat wabah covid-19. Jika bank syariah sebagai salah satu lembaga yang dapat berkontribusi dalam mengembangkan UMKM. Hanya saja pada kondisi saat ini bank syariah juga tergerus akibat wabah covid-19. Apalagi bank syariah belum mengoptimalkan penyaluran pembiayaan untuk kegiatan prouktif untuk UMKM. Dibutuhkan lembaga lain yang dapat ikut membantu dan berkotribusi dalam mengembangkan UMKM di tengah wabah coid-19. Salah satu lembaga yang apat berkontribusi dalam pengembangan UMKM yaitu fintech syariah. Lembaga fintech melakukan banyak kegiatannya dengan mengadalakan transaksi secara tidak langsung bertemu atau melalui online. Fintech dapat memperoleh dana masyarakat dan menyalurkan pembiayaan ke sektor usaha tanpa bertemu langsung, melainkan dengan memanfaatkan kemajuan teknologi. Hal ini sejalan dengan kondisi saat ini, ditengah adanya wabah covid-19, adanya peringan social distancing (jaga jarak), tepat bagi fintech tetap dapat melakukan kegiatan tanpa bertemu langsung. Saat ini juga telah bermunculan perusahaan-perusahaan fintech syariah, dengan berbagai variasi produk seperti peer to peer landing.

\footnotetext{
${ }^{7}$ Kristian, Aknolt Pakpahan. COVID-19 dan Implikasi Bagi Usaha Mikro, Kecil, dan Menengah. (Parahyangan: Jurnal Ilmiah Hubungan Internasional. Universitas Katolik Parahyangan. Volume Volume 16 Nomor 1. Universitas Katolik Parahyangan. 2020)

${ }^{8}$ Hardilawati, W. laura. Strategi Bertahan UMKM di Tengah Pandemi Covid-19. (Jurnal Akuntansi Dan Ekonomika. 2020)
} 
Ronal Yusuf Wijaya selaku ketua umum Asosiasi Fintech Syariah Indonesia (AFSI) mengatakan bahwa wabah corona menjadi penyebab industri fintech syariah ikut mengalami penurunan skala bisnis tingkat penurunan mencapai 60\%-100\%. AFSI memandang bahwa masyarakat tidak begitu memahami konsep syariah. Dia menjelaskan bahwa fenomena tersebut menjadi tugas perlu adanya edukasi secara berkelanjutan untuk meningkatkan pengetahuan dan pemahaman masyarakat, untuk menggali potensi yang lebih baik. "Masyarakat juga belum mengenal ada sistem berinvestasi ataupun mendapatkan pembiayaan atau kredit dengan menggunakan teknologi dari platform online. Sehingga edukasi maupun seminar menjadi penting saat ini agar masyarakat lebih mengenal dan tertarik menggunakan layanan keuangan berbasis teknologi," jelasnya. la juga mengatakan, sampai saat ini terus berusaha untuk melakukan kerjasama dengan beberapa pihak termasuk dengan beberapa kementerian untuk terus melakuka edukasi di tengah masyarakat. Berbagai kegiatan dilakukan seperti melalui seminar maupun kegiatan lain yang mampu meningkatkan pemahaman masyarakat. Ronald berkeinginan untuk memajukan industri fintech syariah, pihaknya gencar lakukan kolaborasi dan bekerjasama dengan beberapa pihak. Di tengah pandemi banyak sektor yang terkena dampak, tetapi juga dapat menjadi peluang. Tantangan di tengah pandemi covid-19, kemudian tingkat literasi masyarakat yang masih kurang juga menjadi suatu hambatan. AFSI terus melakukan upaya untuk juga menjalin kerjasama dengan sektor-sektor tertentu agar bisnis tetap dapat berjalan. Di tengah pandemi banyak bisnis yang tertekan terkena dampak, termasuk pelaku bisnis UMKM. Adapun AFSI telah mencatat telah menyalurkan dana sebesar Rp 1,3 triliun kepada Usaha Mikro Kecil Menengah (UMKM). ${ }^{9}$

Berdasarkan uraian diatas penulis merasa tertarik untuk melakukan penelitian lebih dalam terkait upaya pengembangan UMKM melalui fintech syariah khususnya dalam kondisi di tengah wabah covid-19. Adapun tujuan dalam penelitian yaitu untuk mengetahui perkembangan fintech syariah di Indonesia, dan upaya pengembangan umkm melalui fintech syariah di tengah wabah covid-19. Kemudian tujuan dari penelitian yaitu untuk mengetahui perkembangan fintech syariah di Indonesia dan untuk mengetahui upaya pengembangan UMKM melalui fintech syariah.

\section{Landasan Teori}

Sebelum melakukan penelitian, peneliti berusaha menelaah literatur karya ilmiah sebelumnya yang berkaitan dengan judul yang diteliti dalam hal ini tentang investasi syariah, fintech syariah, dan UMKM. Hasil penelitian-penelitian yang pernah dilakukan sebelumnya perlu dikemukakan sebagai bahan perbandingan dengan penelitian yang dilakukan penulis. Adapun karya-karya ilmiah yang relevan dengan topik yang peneliti angkat antara lain:

9 Dikutip dari https://keuangan.kontan.co.id/news/afsi-bisnis-fintech-syariah-tersengat-pandemicorona, pada tanggal 12 Juli 2020. 
Singgih Muheramtohad dalam penelitiannya yang berjudul Peran Lembaga Keuangan Syariah dalam Pemberdayaan UMKM di Indonesia. Menyebutkan bahwa Karakteristik UMKM adalah beromzet relatif rendah, mempunyai peralatan seadanya (tradisional/manual), dan punya pangsa pasar lebih sempit. Mereka juga membutuhkan modal untuk mengembangkan usaha. Bidang inilah yang perlu diisi oleh lembaga keuangan syariah. Dimana dalam syariat Islam, sektor pembiayaan untuk usaha riil dipraktekkan secara langsung, baik oleh Rasulullah maupun oleh para sahabat Nabi, termasuk Sahabat Umar Ibn Khatab. Pemberian pembiayaan kepada UMKM lebih efektif, karena dialokasikan benar-benar pada kebutuhan usaha kecil secara langsung. Pertimbangan lain yang harus diperhatikan oleh pemerintah adalah bahwa landasan filosofis negara ini adalah Pancasila. Dalam hal ini, negara berdasarkan atas Keadilan Sosial Bagi Seluruh Rakyat Indonesia. ${ }^{10}$

Wahid Wachyu Adi Winarto dalam penelitiannya yang berjudul Peran Fintech dalam Usaha Mikro Kecil dan Menengah (UMKM), menyimpulkan bahwa Fintech memiliki dalam meningkatkan literasi keuangan di kalangan para pelaku UMKM di kabupaten Pekalongan, kabupaten Batang dan kabupaten Pemalang Jawa Tengah. $\mathrm{Hal}$ ini dapat terlihat dari rata-rata adanya peningkatan penggunaan produk dan jasa layanan perbankan, kondisi koperasi simpan pinjam dan lembaga keuangan lain sebesar $6.40 \%$ sebelum adanya Fintech. Peran Fintech dalam meningkatkan inklusi keuangan bagi pelaku UMKM di kabupaten Pekalongan, kabupaten Batang dan kabupaten Pemalang terus meningkat dengan baik. Hal ini dapat dilihat dari para pelaku UMKM banyak yang menggunakan aplikasi dan melakukan kerjasama baik dengan pihak perbankan maupun lembaga koperasi simpan pinjam sehingga memudahkan bagi pelaku UMKM dapat mengakses berbagai jenis layanan keuangan yang disediakan oleh bank dan koperasi simpan pinjam, sekarang lembaga keuangan mampu menjangkau lebih luas seluruh UMKM hingga berbagai daerah termasuk lokasi yang terpencil. Kehadiran fintech telah membuka akses pembiayaan usaha yang lebih mudah, lebih cepat, lebih efisien dari lembaga perbankan dan koperasi simpan pinjam sebelumnya. Peran fintech terakhir bagi inklusi keuangan untuk UMKM adalah fintech akan berkontribusi besar dalam mendorong perkembangan bagi pemberdayaan UMKM khususnya ekonomi lokal. ${ }^{11}$

Lilik Rahmawati dan para rekannya, telah melakukan penelitian yang bertemkan Fintech Syariah: Manfaat dan Problematika Penerapan pada UMKM. Diuraikan dalam penelitian tersebut bahwa perkembangan financial teknologi saat ini tidak hanya dirasakan oleh fintech konvensional semata, namun juga terjadi perkembangan fintech berbasis syariah, kini sudah mulai berkembang di masyarakat. Fintech syariah adalah sebuah bentuk inovasi untuk memeberikan akses dan pelayanan keuangan

\footnotetext{
10 Singgih, Muheramtoh. Peran Lembaga Keuangan Syariah dalam Pemberdayaan UMKM di Indonesia. (Salatiga: Jurnal Muqtasid, Jurnal Ekonomi dan Perbankan Syariah. IAIN Salatiga Volume 8, Nomor 1. 2017)

${ }^{11}$ Wahid Wachyu Adi Winarto. Peran Fintech dalam Usaha Mikro Kecil dan Menengah (UMKM). (Sibolga: Jurnal Ekonomi \& Ekonomi Syariah Sekolah Tinggi Ilmu Ekonomi (STIE) Al-Washliyah Sibolga Volume 3 Nomor 1. 2020)
} 
dengan memanfaatkan teknologi tetapi tetap sejalan dengan dan syariat Islam yang tujuannya agar masyarakat dapat dengan mudah mengakses produk serta menggunakan layanan keuangan yang belum ada padakeuangan tradisional. Meskipun terdapat beberapa kendala yang dihadapi dalam seperti kurangnya pengetahuan masyarakat terkait dengan teknologi, disebabkan karakter masyarakatnya yang tradisional. Fintech syariah terus melakukan inovasi agar dapat diterima dengan baik dan mencari solusi dari kendala yang dihadapi oleh masyarakat. Adapun keuntungan yang di dapat diperoleh dengan hadirnya fintech syariah ialah kemudahan akses dalam pembiayaan bagi para UMKM di Indonesia, pelaku UMKM sebagai penerima dana pinjaman tidak perlu bertemu langsung dengan pemberi dana pinjaman pada saat melakukan pembiayaan, sehingga kebutuhan pembiayaan dapat dipenuhi dengan mudah dan dilakukan tetap sesuai prinsip syariat Islam. ${ }^{12}$

Adapun yang menjadi pembeda penelitian ini dengan penelitian-penilitian terdahulu yang disebutkan diatas, yaitu disesuaikan kondisi saat ini, dampak wabah covid-19 terhadap keberdaan UMKM. Kemudian fintech syariah yang ditekankan pada jenis fintech peer to peer ( $p 2 p$ ) landing yang berbasis syariah, termasuk perkembangan fintech syariah itu sendiri. Kemudian bentuk peran fintech syariah dalam memulihkan UMKM yang terkena dampak wabah covid-19.

\subsection{Fintech Syariah}

Fintech adalah sebuah sebutan yang disingkat dari kata 'financial' dan 'technology' di mana artinya adalah sebuah inovasi di dalam bidang jasa keuangan. Inovasi yang ditawarkan Fintech sangat luas dan dalam berbagai segmen, baik itu B2B (Business to Business) hingga B2C (Business to Consumer). Fintech mempengaruhi kebiasaan transaksi masyarakat menjadi lebih praktis dan efektif. Fintech pun membantu masyarakat untuk lebih mudah mendapatkan akses terhadap produk keuangan dan meningkatkan literasi keuangan. Manfaat Fintech sangat mempengaruhi gaya hidup masyarakat ekonomi. Perpaduan antara efektivitas dan teknologi memiliki dampak positif bagi masyarakat pada umumnya. Terdapat beberapa manfaat adanya Fintech di lingkungan masyarakat, manfaat pertama yaitu, Fintech dapat membantu perkembangan baru di bidang startup teknologi yang tengah menjamur. Hal ini dapat membantu perluasan lapangan kerja dan meningkatkan pertumbuhan ekonomi. ${ }^{13}$

Financial Technology merupakan pemanfaatan teknologi untuk mendukung kegiatan atau transaksi keuangan keuangan. Financial Technologhy saat ini lebih dikenal dengan istilah 'fintech' yang merupakan suatu program komputer atau penggunaan teknologi lainnya pemanfaatannya mendukung serta mengaktifkan layanan perbankan dan jasa keuangan tanpa adanya transaksi secara langsung. Kemudian

\footnotetext{
12 Lilik, Rahmawati. dkk. Fintech Syariah: Manfaat dan Problematika Penerapan Pada UMKM. (Surabaya: Jurnal Masharif al-Syariah: Jurnal Ekonomi dan Perbankan Syariah. Volume 5, No. 1, 2020. Universitas Muhammadiyah Surabaya. 2020

${ }^{13}$ Dikutip dari https://www.finansialku.com/definisi-fintech-adalah/, pada tanggal 10 Juni 2018
} 
Fintech merupakan suatu bisnis memiliki tujuan sebagai penyedia jasa keuangan melalui perangkat lunak didukung dengan teknologi modern. Fintech merupakan suatu bentuk kombinasi pemanfaatan teknologi keuangan yang bagi sektor jasa keuangan yang telah ada di abad ke-21. Sebelumnya, istilah yang dikenal untuk teknologi diterapkan pada back-end dari konsumen yang telah ada, serta digunakan oleh perdagangan lembaga keuangan. Pada akhir dekade pertama abad ke-21, istilah ini semakin meliuas mencakup adanya inovasi teknologi dibidangan keuangan, kemudian inovasi di bidang pendidikan, serts kecerdasan finansial, perbankan yang ritel, kegiatan investasi, bahkan juga digunakan pada mata uang kripto seperti bitcoin. Kehadiran fintech mampu mendukung industri ekonomi bagi perusahaan yang menggunakan teknologi yang memberikan jasa keuangan sehingga lebih efisien. Sangat tidak mudah untuk mendefinisikan Fintech secara utuh, karena definisi yang ada bersifat fleksibel masih dapat berubah dari waktu ke waktu. Karena sistem perbankan yang masih tradisional sulit berkembang akibat warisan sistem operasional yang masih diberlakukan. Padahal harus ada upaya untuk berinovasi, kemudian kecepatan dan memiliki keahlian di bidang teknologi. Kehadiran fintech umumnya merupakan bentuk bisnis startup bertujuan untuk menawarkan sistem bagi perusahaan keuangan yang, tetapi masih kurang mengoptimalkan para penggunaan teknologi sehingga menghadirkan software. ${ }^{14}$ Fintech di Indonesia memiliki beberapa jenis, seperti startup yang memberikan layanan pembayaran, layanan dalam bentuk riset keuangan, sarana investasi ritel, penyaluran pembiayaan/ kredit (lending \& crowdfunding), bentuk perencanaan keuangan (personal finance), dan jasa remitansi.

Fatwa Dewan Syariah Nasional Majelis Ulama Inonesia (DSN MUI) menyebutkan bahwa layanan pembiayaan berbasis teknologi informasi untuk pelaku usaha skala mikro, kecil, dan menengah (UMKM) dalam upaya memperoleh akses pendanaan secara cepat, mudah, dan efisien saat ini semakin berkembang di Indonesia. Layanan Pembiayaan Berbasis Teknologi Informasi Berdasarkan Prinsip Syariah adalah penyelenggaraan layanan jasa keuangan berdasarkan prinsip syariah yang mempertemukan atau menghubungkan Pemberi Pembiayaan dengan Penerima Pembiayaan dalam rangka melakukan akad pembiayaan melalui sistem elektronik dengan menggunakan jaringan internet. Sistem Elektronik adalah serangkaian perangkat dan prosedur elektronik yang berfungsi mempersiapkan, mengumpulkan, mengolah, menganalisis, menyimpan, menampilkan, mengumumkan, mengirimkan, dan/atau menyebarkan informasi elektronik di bidang layanan jasa keuangan. Teknologi Informasi adalah suatu teknik untuk mengumpulkan, menyiapkan, menyimpan, memproses, mengumumkan, menganalisis, dan/atau menyebarkan informasi di bidang layanan jasa keuangan. ${ }^{15}$

\footnotetext{
${ }^{14}$ Dikutipdari http://binus.ac.id/malang/2017/09/mengenal-fintech-sebagai-inovasi-bisnis-keuangan/, pada tanggal 10 Juni 2018.

${ }^{15}$ Fatwa DSN-MUI Nomor 117/DSN-MUI/II/2018
} 


\subsection{Usaha Mikro Kecil dan Menengah (UMKM)}

Kuncoro dalam Roswita (2017) menyebutkan ada dua definisi UMKM yang dikenal di Indonesia. Pertama, definisi usaha menurut undang-undang (UU) Nomor 20 Tahun 2008 tentang Usaha Mikro, Kecil dan Menengah. Menurut UU ini, usaha kecil didefinisikan sebagai kegiatan ekonomi produktif yang berdiri sendiri, yang dilakukan oleh orang perorangan atau badan usaha yang bukan merupakan anak perusahaan atau bukan cabang perusahaan yang dimiliki, dikuasai, atau menjadi bagian, baik langsung maupun tidak langsung, dari usaha menengah atau usaha besar, serta memenuhi kriteria antara lain: kekayaan bersih Rp.50 juta sampai Rp.500 juta tidak termasuk tanah dan bangunan tempat usaha, atau memiliki hasil penjualan tahunan Rp.300 juta sampai Rp.2,5 miliar. Sedangkan bagi usaha mikro, dimana usaha tersebut sebuah usaha produktif mili orang perorangan atau badan usaha perorangan, serta memenuhi kriteria antara lain: kekayan bersih paling banyak Rp.50 juta, atau memilki total omzet paling banyak Rp.300 juta per tahun. Dan terakhir usaha menengah yaitu, usaha ekonomi produktif yang berdiri sendiri, yang dilakukan oleh orang perseorangan atau badan usaha yang bukan merupakan anak perusahaan atau cabang perusahaan yang dimiliki, dikuasai, atau menjadi bagian baik langsung maupun tidak langsung dengan usaha kecil atau usaha besar. Serta memenuhi kriteria antara lain: kekayaan bersih Rp.500 juta sampai dengan Rp.10 miliar, atau memiliki hasil usaha penjuala tahunan lebih dari Rp.2,5 miliar sampai Rp.50 miliar. ${ }^{16}$

Peran usaha mikro, kecil dan menengah (UMKM) dalam perekonomian Indonesia paling tidak dapat dilihat dari: (1) kedudukannya sebagai pemain utama dalam kegiatan ekonomi di berbagai sektor, (2) penyedia lapangan kerja yang terbesar, (3) pemain penting dalam pengembangan kegiatan ekonomi lokal dan pemberdayaan masyarakat, (4) pencipta pasar baru dan sumber inovasi, serta (5) sumbangannya dalam menjaga neraca pembayaran melalui kegiatan ekspor (KEMEN KUKM, 2005). Usaha mikro merupakan kelompok pelaku usaha terbesar (96\%) di Indonesia dengan karakteristik berpenghasilan rendah, bergerak di sektor informal dan sebagian besar termasuk dalam kelompok keluarga miskin. Bahkan dalam sebagian besar kasus, kelompok usaha mikro masih belum dapat memenuhi kebutuhan dasar untuk hidup, seperti: gizi, pendidikan, kesehatan dan lain-lain. Usaha mikro memiliki karakteristik yang unik dan belum tentu dapat diberdayakan secara optimal melalui mekanisme pasar yang bersaing. Untuk itu, pemberdayaan usaha mikro perlu ditetapkan sebagai suatu strategi yang tersendiri, melalui pengembangan pranata kelembagaan usaha mikro, pengembangan lembaga keuangan mikro dan mendorong pengembangan industri pedesaan. ${ }^{17}$

\footnotetext{
${ }^{16}$ Roswita dan Ahmad Rozali. Analisis Usaha Mikro, Kecil, dan Menengah (UMKM) Terhadap Penyerapan Tenaga Kerja di Indonesia. (Sumatra Utara: Jurnal Ekonomikawan Jurnal Ilmu Ekonomi dan Studi Pembangunan. 2017)

17 Adnan Husada Putra. Peran UMKM Dalam Pembangunan dan Kesejahteraan Masyarakat Kabupaten Blora. (Surakarta: Jurnal Analisa Sosiologi (JAS) Program Studi Magister Sosiologi Fakultas Ilmu Sosial dan Politik Universitas Sebelas Maret. 2016)
} 
Perusahaan kecil dikelola atau dipimpin sendiri oleh pemilik perusahaan. Struktur organisasi perusahaan sederhana dan masih banyak rangkap jabatan. Kemungkinan kegagalan perusahaan relatif tinggi. Usaha sulit berkembang karena sulitnya mendapat pinjaman dengan syarat lunak. Cara mengembangkan perusahaan kecil yaitu; menggalakkan minat usaha (sense of business) di kalangan masyarakat. Lalu memberikan bantuan kredit bank bersyarat lunak kepada pengusaha kecil. Kemudian meningkatkan keterampilan dan memperluas peluang kerja. Selanjutnya membentuk dan mengaktifkan sentra industri kecil. Serta mengurangi investasi padat modal dan mendorong sistem mitra usaha "bapak angkat" perusahaan besar terhadap kecil. Terakhir membentuk inkubator bisnis untuk memfasilitasi pengembangan usahawan pemula. ${ }^{18}$

Empat alasan yang menjelaskan posisi strategis UMKM di Indonesia. Pertama, UMKM tidak memerlukan modal yang besar sebagaimana perusahaan besar sehingga pembentukan usaha ini tidak sesulit usaha besar. Kedua, tenaga kerja yang diperlukan tidak menuntut pendidikan formal tertentu. Ketiga, sebagian besar berlokasi di pedesaan dan tidak memerlukan infrastruktur sebagaimana perusahaan besar. Keempat, UMKM terbukti memiliki ketahanan yang kuat ketika Indonesia dilanda krisis ekonomi. ${ }^{19}$

Pembiayaan bagi usaha ritel merupakan pembiayaan yang disalurkan bagi usaha perorangan atau berbentuk badan usaha yang digunakan untuk mendukung kegiatan usaha. Besaran jumlah penyaluran pembiayaan yang diberikan bank syariah pada segemen ritel bervariasi. Ada beberapa faktor yang menjadi alasan kegiatan usaha yang dimiliki perorangan ataupun badan usaha memerlukan dukungan pembiayaan ritel dari bank syariah. Misalnya, penyaluran pembiayaan untuk penambahan persedian barang (inventory) yang dibutuhkan dari usaha atau menjaga persediaan barang produksi pada level minimum. Biasanya tagihan dari para supplier barang lebih cepat dibandingkan pembayaran dari para custumer. Bahkan ada beberapa customer meminta pengajuan penundaan pembayaran. Diversifikasi berbagai usaha dan produk dari ekspansi bisnis banyak membutuhkan kantor baru atau peralatan perlengkan kantor untuk produksi barang baru. Kemudian digunakan untuk modernisasi peralatan atau perlengkapan yang dibutuhkan dari suatu usaha. Pada umumnya pembiayaan berskala ritel maupun pembiayaan yang tujuannya produktif dibagi menjadi dua, yaitu cash financing dan non-cashfinancing. Pembiayaan yang diperuntuhkan untuk modal kerja usaha (PMK) merupakan pembiayaan yang diberikan oleh bank syariah untuk membantu kebutuhan modal kerja usaha untuk perputaran usaha nasabah pembiayaan agar usaha dapat terus berjalan dengan lancar. Pada perbankan syariah jenis pembiayaan modal kerja biasanya menggunakan akad musyarakah atau akad mudharabah, yang merupakan akad kerjasama dengan skema bagi hasil. Sedangkan bagi pembiayaan untuk modal kerja

\footnotetext{
${ }^{18}$ Susatyo Herlambang dan Bambang Heru Wartono. Pengantar Ilmu Bisnis. (Yogyakarta: Parama Publishing. 2014)

${ }^{19}$ Sudati Nur Sarfiah, dkk. UMKM Sebagai Pilar Pembangunan Ekonomi Bangsa. (Magelang: Jurnal Risat Ekonomi Pembangunan Universitas Tidar. 2019)
} 
yang tujuannya pengadaan barang, seperti untuk aset, tangible asset, maka akad yang banyak digunakan adalah skema jual beli dengan akad murabahah. ${ }^{20}$

Diketahui bahwa sektor swasta didominasi oleh skala usaha mikro. Hal ini juga dapat berarti bahwa animo masyarakat sangat besar untuk membuka usaha atau menjadi entrepreneur. Selanjutnya adalah bagaimana menjadikan usaha-usaha berskala mikro mampu mencapai skala besar, sehingga mampu meningkatkan kondisi ekonomi nasional. Berdasarkan kontribusi UMKM terhadapa Produk Domestik Bruto (PDB) persektor dapat diketahui kontribusi UMKM terbesar berada di sektor Pertanian, Peternakan, Kehutanan, dan Perikanan (PPKP) dengan unit UMKM sebesar 49,58 persen., disusul dengan sektor Perdagangan, Hotel, dan Restoran (PHR) sebesar 29,56 persen. Industri pada sektor ini sangat potensial dikembangkan sejak dari mikro, dan ada peluang dikembangkan untuk menjadi industri besar. ${ }^{21}$

Peran lembaga keuangan untuk mengalirkan harta tentunya sangat penting. Naman, konsep ekonomi Islam selalu mengharuskan pergerakan arus uang harus diikuti oleh pergerakan di sektor riil. Dengan kata lain, transaksi di sektor keuangan merupakan refleksi dari transaksi yang terjadi di sektor riil. Hal ini sangat berbeda dengan konsep yang ada pada sistem ekonomi konvensional yang menempatkan pasar keuangan sejajar dengan pasar sektor riil. Dengan konsep ini, lazim terjadi adanya transaksi di sektor keuangan yang sama sekali tidak ada kaitannya dengan transaksi di sektor riil (decoupling). Hal ini berpotensi terjadinya akselerasi pertumbuhan yang sama di sektor riil sehingga dapat memicu risiko bubble. Risiko ini kecil kemungkinannya terjadi di dalam sistem ekonomi berbasis syariah yang diterapkan secara benar dan istiqomah. Ekonomi syariah menekankan bahwa harta memiliki peran efektif dalam memfasilitasi kegiatan perdagangan, investasi, dan peningkatan kesejahteraan sosial masyarakat. ${ }^{22}$

Selain akses pembiayaan, UMKM juga menemui kesulitan dalam hal akses terhadap informasi. Minimnya informasi yang diketahui oleh UKM, sedikit banyak memberikan pengaruh terhadap kompetisi dari produk ataupun jasa dari unit usaha UMKM dengan produk lain dalam hal kualitas. Efek dari hal ini adalah tidak mampunyai produk dan jasa sebagai hasil dari UMKM untuk menembus pasar ekspor. Namun, di sisi lain, terdapat pula produk atau jasa yang berpotensial untuk bertarung di pasar internasional karena tidak memiliki jalur ataupun akses terhadap pasar tersebut, pada akhirnya hanya beredar di pasar domestik. Dalam perkembangannya, UMKM menghadapi banyak masalah yang sampai saat ini belum mendapat perhatian serius untuk mengatasinya. Hal tersebut menjadi kendala dalam hal pengolahan data produkproduk unggulan yang dimiliki oleh UMKM dalam suatu daerah. Karena dengan terbatasnya akses informasi data UMKM mengakibatkan rendahnya

\footnotetext{
${ }^{20}$ Ikatan Bankir Indonesia dan Lembaga Sertifikasi Profesi Perbankan. Mengelola Bisnis Pembiayaan Bank Syariah. (Jakarta: PT Gramedia Pustaka Utama. 2015)

${ }^{21}$ Irfan Syauqi Beik dan Laily Dwi Arsyianti. Ekonomi Pembangunan Syariah. (Jakarta: PT RajaGrafindo Persada. 2016)

22 Darsono, dkk. Masa Depan Keuangan Syariah Indonesia. (Bogor: Tazkia Publishing. 2017)
} 
informasi data yang dibutuhkan mengenai UMKM. Miskinnya informasi mengenai data UMKM tersebut, menjadikan UMKM tidak dapat mengarahkan pengembangan usahanya secara jelas dan fokus. ${ }^{23}$

\section{Metode Penelitian}

Penelitian ini menggunakan metode kualitatif dengan pendekatan studi pustaka (library research). Penelitian yang menguraikan dari objek penelitian yang disajikan dalam hal hal ini terkait dengan perkembangan fintech syariah dan upaya pengembangan UMKM melalui fintech syariah khususnya pada masa pandemi covid19.

Sumber data yang digunakan dalam penelitian ini adalah data sekunder yang kemudian diolah oleh peneliti. Data yang telah disajikan oleh beberapa sumber baik dari referensi ataupun dari lembaga tertentu. Sumber data penelitian ini salah satu sumber yang telah disajikan oleh Otoritas Jasa Keuangan (OJK) yang kemudian diolah oleh peneliti. Serta dari beberapa dari sumber lain yang dianggap perlu dalam penelitian ini.

Batasan dalam penelitian ini yaitu fokus hanya pada tema fintech syariah dan UMKM. Teknik pengumpulan data yaitu melalui mengumpulkan sumber-sumber data yang dianggap relevan dengan tema penelitian. Seperti dari jurnal, referensi, ataupun dari sumber-sumber lain yang telah disajikan sebelumnya. Untuk memperolah data yang diperlukan untuk melakukan penelitian.

Teknik analisis data yang digunakan adalah deskriptif kualitatif. Yaitu menguraikan dari objek penlitian, yang kemudian diuraikan dalam bentuk deskripsi dari data yang diperoleh. Diuraikan tentang perkembangan fintech syariah, keberadaan UMKM, dan pengembangan UMKM melalui layanan yang diberikan oleh fintech syariah. Dari kondisi dari analisis data maka peneliti memberikan uraian dari data-data yang diperoleh.

\section{Hasil dan Pembahasan}

\subsection{Perkembangan Fintech Syariah di Indonesia}

Data yang telah dikeluarkan oleh Otoritas Jasa Keuangan (OJK) yang tertuang dalam Statistik Fintech Lending Periode April 2020 menunjukkan bahwa aset Fintech mencapai 3.614.528.740.453 rupiah. Pelaku fintech dibagi dua ada yang berstatus Terdaftar dan ada yang berstatus berizin. Jumlah pelaku fintech sebanyak 161 perusahaan. Pelaku fintech dibagi dua fintech konvensional dengan fintech syariah. Fintech konvensional berjumlah 149. Dan fintech syariah sebanyak 13 . Fintech konvensional terdiri dari 125 perusahaan fintech terdaftar dan 24 perusahaan

\footnotetext{
${ }^{23}$ Mariana Kristiyanti dan Lisda Rahmasari. Websait Sebagai Media Pemasaran Produk-Produk Unggulan UMKM di Kota Semarang. (Malang: Jurnal Aplikasi Manajemen Universitas Brawijaya. 2015)
} 
fintech yang berizin. Adapun perusahaan fintech syariah 11 perusahaan teraftar dan 1 perusahaan fintech syariah berizin.

Total aset fintech syariah sebesar 50.591.727.786 rupiah, atau 1,4 persen dari total aset fintech secara keseluruhan. Jumlah dintech yang telah telah terdaftar dan berizin di OJK yaitu sebanyak 161 perusahan, dan 7,5 persen merupakan fintech syariah atau sebanyak 13 perusahaan. Dari 13 perusahaan fintech ada 6 perusahaan fintech syariah yang fokus pada penyaluran pembiayaan UMKM. Adapun 13 fintech syariah tersebut yaitu;

a. PT Ammana Fintek Syariah

b. PT Dana Syariah Indonesia

c. PT Danakoo Mitra Artha

d. PT Alami Fintek Sharia

e. PT Syarfi Teknologi Finansial

f. PT Duha Madani Syariah

g. PT Qazwa Mitra Hasanah

h. PT Maslahat Indonesia Mandiri

i. PT Ethis Fintek Indonesia

j. $\quad$ PT Kapital Boost Indonesia

k. PT Piranti Alphabet Perkasa

I. PT Berkah Finteck Syariah

m. PT Investree Radhika Jaya (Syariah/ Konvensional)

Ada 6 perusahaan fintech syariah yang fokus pada penyaluran pembiayaan pada sektor usaha UMKM yaitu;

a. PT. Ammana sebagai fintech yang hadir dengan layanan digital sebagai jembatan kolaborasi bagi pihak pendanaan bersama para lender dan peminjam (borrower), akan saling menguntungkan semua pihak. Layanan ini dapat menciptakan sebuah bentuk komunitas yang unik dan tak terbatas oleh ruang dan memberi garis demografis. PT Ammana sebagai perusahaan fintech bentuk perwujudan dari solusi pendanaan berbasis digital untuk memperkuat ukhuwah dibidang ekonomi yang berfungsi memastikan kiprah para pelaku UMKM dapat maju, kemudian menjadi pelaku usaha unggul, usaha yang sukses, hidup yang lebih berkah dan mampu menjadi pemain utama dalam mendukung perkembangan bagi Industri halal di Indonesia. Kedepannya akan menjadi sebuah kebanggaan untuk mendukung kemajuan salah satu sektor ekonomi mikro Indonesia yaitu dengan mendukung kemajuan para pelaku UMKM sebagai perluasan pemanfaatan teknologi fintech dan pendanaan prinsip kebersamaan bagi usaha produktif dan halal. Dengan pendanaan bersama serta adanya dukungan teknologi digital, akan menjadi bagian dari mata rantai bersifat kebaikan 
bertujuan meningkatkan kesejahteraan ekonomi bagi para pelaku UMKM sekaligus membebaskan mereka dari ancaman permodalan ribawi karena fintech syariah menerapakan prinsip syariah Islam. ${ }^{24}$

b. PT. ALAMI adalah peer-to-peer financing syariah di Indonesia yang mempertemukan UKM dengan pemberi pembiayaan. Teknologi kami menganalisa ratusan data untuk menghasilkan pembiayaan yang memiliki kualitas dan kredibilitas yang baik. Menjadikan para pihak lebih efisien, akurat, dan transparan dalam proses pembiayaan syariah. Didirikan oleh profesional muda yang bersemangat memajukan industri keuangan syariah. Sejak awal dibentuk, ALAMI patuh dengan ketentuan regulator yang berlaku dengan pencatatan model bisnis agregator dan juga pendaftaran model bisnis P2P. Kami juga melakukan korespondensi dari awal dengan Dewan Syariah Nasional Majelis Ulama Indonesia. ALAMI juga terdaftar dengan Kementerian Komunikasi dan Informasi. ${ }^{25}$

c. Pendanaan Mudharabah adalah pendanaan usaha rakyat yang memberikan akses pendanaan kepada masyarakat sebagai pengguna (user) Berkah Fintek Syariah baik penerima pendanaan dan pemberi pendanaan untuk modal usaha (produktif) peternakan, modal usaha industri kecil menengah (IKM) dan modal usaha (produktif), Usaha Kecil Menengah (UKM) sesuai dengan prinsip syariah. Dalam hal ini penerima pendanaan dapat mengajukan permohonan modal usaha (produktif) kepada Berkah Fintek Syariah, sekaligus sebagai wakil melalui kontrak perjanjian (akad) wakalah bi al Ujrah. Sebagai wakil, Berkah Fintek Syariah akan menghubungkan penerima pendanaan kepada pemberi pendanaan, yang sebelumnya juga mewakilkan kepada Berkah Fintek Syariah melalui akad wakalah bi al Ujrah. Selanjutnya, Berkah Fintek Syariah mempertemukan pihak penerima pendanaan kepada pemberi pendanaan, keduanya saling menyetujui dengan menandatangi akad mudharabah untuk pendanaan usaha produktif dengan menunjukan modal pokok dan ditambah nisbah (bagi hasil) sebagai keuntungan yang menjadi hak bagi pemberi pendanaan. ${ }^{26}$

d. Kapital Boost adalah platform peer-to-peer pembiayaan syariah untuk UKM. Berdiri pada tahun 2016, Kami telah membantu berbagai UKM di Singapura, Indonesia dan Malaysia untuk mendapatkan modal kerja dari para pendana global. Peer-to-Peer pembiayaan syariah Kapital Boost mengedepankan kemudahan, keadilan dan transparansi untuk semua pengguna. ${ }^{27}$

e. PT. Qazwa Mitra Hasanah diisi oleh tim yang mempunyai semangat menyebarkan ekonomi islam. Melalui pengembangan teknologi dan akses keuangan, kami bekerja keras untuk mewujdukan ekonomi islam yang

\footnotetext{
${ }^{24}$ Dikutip dari https://ammana.id/

${ }^{25}$ Dikutip dari https://p2p.alamisharia.co.id

${ }^{26}$ Dikutip dari https://www.finteksyariah.co.id

${ }^{27}$ Dikutip dari $h$ ttps://kapitalboost.co.id
} 
bermanfaat untuk setiap orang. Qazwa adalah media investasi berbasis syariah yang bertujuan untuk memudahkan UMKM mendapatkan akses permodalan untuk mengembangkan usahanya. Qazwa hadir sebagai pionir teknologi keuangan berbasis syariah terdepan di indonesia yang memiliki misi menciptakan akses keuangan yang inklusif dan membebaskan UMKM dari jeratan riba. ${ }^{28}$

f. Investree adalah perusahaan teknologi finansial di Indonesia dengan sebuah misi sederhana: sebagai online marketplace yang mempertemukan orang yang memiliki kebutuhan pendanaan dengan orang yang bersedia meminjamkan dananya. Tak hanya meningkatkan perolehan Lender, kami juga membuat pinjaman menjadi lebih terjangkau dan mudah diakses bagi Borrower. Peer-topeer marketplace merupakan suatu wadah yang mempertemukan banyak orang yang membutuhkan pinjaman dengan banyak orang lainnya yang bersedia memberikan pinjaman. Peran Investree adalah menjalankan marketplace tersebut. Bagaikan pusat perbelanjaan, tugas kami adalah menyediakan ruang eksklusif bagi para penjual dan pembeli untuk saling bertemu. Tak hanya itu, kami juga menyeleksi, menganalisis, dan menyetujui aplikasi pinjaman yang diajukan oleh Borrower agar menghasilkan pendanaan yang berkualitas untuk ditawarkan kepada para Pendana. ${ }^{29}$

\subsection{Upaya Pengembangan UMKM melalui Fintech Syariah}

Fintech syariah sebagai salah satu lembaga keuangan syariah yang terbilang masih baru dapat berperan dalam pemulihan UMKM yang terkena dampak dari wabah covid-19. Bentuk peran yang dapat dilakukan yaitu dengan adanya penyaluran modal usaha bagi pelaku UMKM. Kemudian peran fintech dapat berupa pendampingan usaha bagi para pelaku UMKM yang terkena dampak wabah covid-19 memberikan pendampingan atau pelatihan pemasaran produk melalui media online. Sebagaimana pola kerja dari fintech syariah itu sendiri yang mengandalkan kegiatannya menggunakan teknologi. Pelaku UMKM yang mendapatkan penambahan modal usaha dari fintech syariah harus disertai dengan pelatihan dan pendampingan dalam usaha. UMKM yang terkena dampak dapat mengubah pola pemasaran usahanya dengan bantuan fintech, jika sebelumnnya banyak bertransaksi secara offline dapat diubah menjadi online. Selain itu peran fintech juga dapat berupa penyaluran dana yang bersifat dana sosial, yang disalurkan bagi pelaku usaha UMKM yang sudah sangat mendesak, dan membutuhkan segera modal. Disamping pelatihan pemasaran produk melalui media online, fintech syariah juga memberikan dukungan agar pelaku UMKM dapat membuat produk-produk baru yang dibutuhkan di tengah kondisi wabah covid-19.

Kondisi UMKM yang terkena dampak covid-19 fintech syariah harus tetap mampu menjaga UMKM yang telah diberikan pembiayaan. Peran fintech syariah bukan hanya untuk keuangan tapi harus lebih lagi, khususnya bagaimana UMKM ini bisa

\footnotetext{
${ }^{28}$ Dikutip dari https://qazwa.id

${ }^{29}$ Dikutip dari https://investree.id/about-us
} 
kembali bertahan, fintech syariah dapat mendampingi usaha pelaku UMKM. Fintech syariah dapat menjadi katalis, yang memberikan pendampingan kepada para UMKM. Fintech syariah melakukan kegiatannya melalu transaksi online tidak bertemu langsung dengan mitranya. Cara seperti ini juga bisa disampaikan pada UMKM. Fintech syariah bisa mengenali jenis dan produk-produk UMKM sehingga dapat dibantu pada pemasaran produknya. UMKM diberi ruang marketplace di situs milik fintech syariah, agar UMKM dapat dikenal secara luas, kemudian dapat menjadi media dalam pemasaran produk dari UMKM mitra. Selain itu fintech syariah dapat menjadi katalis dalam hal produk-produk dari UMKM yang sekiranya banyak dibutuhkan di masa pandemi covid-19 ini. Upaya meningkatkan volume untuk pendanaan fintech syariah dapat berkolaborasi dengan bank-bank syariah untuk meningkatkan penyaluran pembiayaan di tengah wabah covid-19. Kondisi yang tidak stabil seperti ini sangat dibutuhkan sinergisitas dan kerjasama antara banyak pihak untuk menggerakkan kembali sektor riil khususnya untuk UMKM. Pihak lembaga keuangan syariah dapat melakukan kerjasama seperti fintech syariah dan bank syariah dalam pengembangan UMKM di tengah wabah covid-19.

\section{Penutup}

Perkembangan fintech syariah berasarkan data yang telah dikeluarkan oleh Otoritas Jasa Keuangan (OJK) paa periode april 2020, jumlah aset sebesar 50.591.727.786 rupiah, atau 1,4 persen dari total aset fintech secara keseluruhan. Aset fintech syariah mengalami pertumbuhan jika dibandingkan periode februari 2020, tumbuh sebesar 8,32 persen. Kemudian saat ini jumlah fintech syariah yang teraftar dan berizin dari OJK sebanyak 13 fintech syariah atau 7,5 persen dari total fintech secara keseluruhan. Ada13 fintech syariah, diantaranya 6 perusahaan fintech syariah yang fokus pada pembiayaan untuk UMKM. Fintech syariah tersebut yaitu PT Ammana Fintek Syariah, PT Alami Fintek Sharia, PT Berkah Finteck Syariah, PT. Kapital Boost Indonesia, PT Qazwa Mitra Hasanah, dan PT Investree Radhika Jaya.

Upaya pengembangan UMKM melalui fintech syariah di tengah wabah covid-19 dapat dilakukan secara kolaborasi. Sistem kerja fintech syariah yang mengandalakan teknologi secara online dalam kegiatannya dapat dikembangkan pada sektor UMKM. UMKM saat ini juga terkena dampak covid-19, sehingga membutuhkan mitra yang mampu membuatnya bertahan. Fintech syariah telah bermitra dengan UMKM dalam bentuk penyaluran pembiayaan. Munculnya wabah covid-19, fintech syariah dapat menambahkan perannya bagi UMKM bukan hanya sekedar penyaluran pembiayaan tetapi juga ikut mendorong perkembangannya khususnya dalam urusan pemasaran produk-produk UMKM mitranya. Fintech syariah dapat menyediakan marketplace untuk UMKM serta menjadi katalis tentang produk-produk yang tepat bagi UMKM untuk diproduksi di tengah wabah covid-19.

Penelitian untuk lebih lanjut dengan tema penelitian yang berbeda, khususnya terkait dengan peran lembaga keuangan syariah di tengah wabah covid-19. Perlu ada penelitian yang lebih koprehensip untuk dapat berkontribusi karena adanya dampak wabah covid-19 bagi banyak segmen. Sehingga penelitian dapat dilakukan terhadap 
segmen-segmen yang terkena dampak, yang kemudian ada upaya untuk memberikan solusi dari pihak yang terkena dampak. Selain penelitian terkait fintech UMKM, dapat dikembangkan pada peran fintech syariah pada segmen lain, dengan menyesuaikan dari kondisi fintech yang terus mengalami pertumbuhan yang baik. Selain fintech syariah banyak instrument keuangan syariah yang dapat berperan bagi pemulihan UMKM perlu dilakukan penelitian dan pengkajian yang lebih lanjut dan berkesinambungan.

\section{DAFTAR PUSTAKA}

Darsono, dkk. Masa Depan Keuangan Syariah Indonesia. Bogor: Tazkia Publishing, 2017.

Hafni, Roswita dan Ahmad Rozali. Analisis Usaha Mikro, Kecil, dan Menengah (UMKM) Terhadap Penyerapan Tenaga Kerja di Indonesia. Sumatra Utara: Jurnal Ekonomikawan Jurnal Ilmu Ekonomi dan Studi Pembangunan, 2017.

Hardilawati, W. laura. Strategi Bertahan UMKM di Tengah Pandemi Covid-19. Jurnal Akuntansi Dan Ekonomika, 2020. https://doi.org/10.37859/jae.v10i1.1934

Herlambang, Susatyo dan Bambang Heru Wartono. Pengantar Ilmu Bisnis. Yogyakarta: Parama Publishing, 2014.

Ikatan Bankir Indonesia dan Lembaga Sertifikasi Profesi Perbankan. Mengelola Bisnis Pembiayaan Bank Syariah. Jakarta: PT Gramedia Pustaka Utama, 2015.

Kristian, Aknolt Pakpahan. COVID-19 dan Implikasi Bagi Usaha Mikro, Kecil, dan Menengah. Parahyangan : Jurnal Ilmiah Hubungan Internasional. Universitas Katolik Parahyangan. Volume Volume 16 Nomor 1. Universitas Katolik Parahyangan, 2020.

Kristiyanti, Mariana dan Lisda Rahmasari. Websait Sebagai Media Pemasaran Produk-Produk Unggulan UMKM di Kota Semarang. Malang: Jurnal Aplikasi Manajemen Universitas Brawijaya, 2015.

Muhamad. Audit dan Pengawasan Syariah Pada Bank Syariah. Yogyakarta: UII Press Yogyakarta, 2011.

Muheramtohad, Singgih. Peran Lembaga Keuangan Syariah dalam Pemberdayaan UMKM di Indonesia. Salatiga: Jurnal Muqtasid, Jurnal Ekonomi dan Perbankan Syariah. IAIN Salatiga, 2017.

Putra, Adnan Husada. Peran UMKM Dalam Pembangunan dan Kesejahteraan Masyarakat Kabupaten Blora. (Surakarta: Jurnal Analisa Sosiologi (JAS) Program Studi Magister Sosiologi Fakultas Ilmu Sosial dan Politik Universitas Sebelas Maret, 2016.

Rahmawati, Lilik.dkk. Fintech Syariah: Manfaat dan Problematika Penerapan Pada UMKM. Surabaya: Jurnal Masharif al-Syariah: Jurnal Ekonomi dan Perbankan Syariah Universitas Muhammadiyah Surabaya, 2020. 
Sarfiah, Sudati Nur, dkk. UMKM Sebagai Pilar Pembangunan Ekonomi Bangsa. Magelang: Jurnal Risat Ekonomi Pembangunan Universitas Tidar, 2019.

Sofyan, Riyanto. Bisnis Syariah Mengapa Tidak ? Jakarta: PT Gramedia Pustaka Utama, 2011.

Syauqi, Irfan Beik dan Laily Dwi Arsyianti. Ekonomi Pembangunan Syariah. Jakarta: PT RajaGrafindo Persada, 2016.

Wachyu, Wahid Adi Winarto. Peran Fintech dalam Usaha Mikro Kecil dan Menengah (UMKM). Sibolga: Jurnal Ekonomi \& Ekonomi Syariah Sekolah Tinggi Ilmu Ekonomi (STIE) Al-Washliyah Sibolga, 2020.

https://www.finansialku.com/definisi-fintech-adalah/, pada tanggal 10 Juni 2018.

http://binus.ac.id/malang/2017/09/mengenal-fintech-sebagai-inovasi-bisniskeuangan/, pada tanggal 10 Juni 2018.

https://fintechsyariah.id/id/about, 25 Februari 2020.

https://republika.co.id/berita/q9sq59383/sejauh-mana-dampak-covid19-terhadapbank-syariah, pada tanggal 9 Juli 2020.

https://republika.co.id/berita/q9sq59383/sejauh-mana-dampak-covid19-terhadapbank-syariah, paa tanggal 9 Juli 2020.

https://www.kompasiana.com/maretaintansari/5ebc0b27d541df248350fec2/pengar uh-covid-19-terhapad-pertumbuhan-umkm-di-indonesia, paa tanggal $10 \mathrm{Juli}$ 2020.

https://www.cnbcindonesia.com/news/20200429173402-8-155339/ini-kata-tetenmasduki-soal-dampak-covid-19-bagi-umkm, pada tanggal 10 Juli 2020.

https://nasional.kontan.co.id/news/menghitung-dampak-covid-19-terhadap-duniausaha-hingga-umkm, pada tanggal 11 Juli 2020.

https://www.ojk.go.id/id/berita-dan-kegiatan/siaran-pers/Pages/Siaran-Pers-OJKKeluarkan-Paket-Kebijakan-Lanjutan-Stimulus-Covid-19-.aspx, 11 Juli 2020.

https://keuangan.kontan.co.id/news/afsi-bisnis-fintech-syariah-tersengat-pandemicorona, pada tanggal 12 Juli 2020.

https://investree.id/about-us

https://p2p.alamisharia.co.id

https://www.finteksyariah.co.id

https://kapitalboost.co.id

https://qazwa.id

https://ammana.id/ 
Dewan Syariah Nasional Majelis Ulama Indonesia (DSN-MUI). Fatwa DSN-MUI Nomor 117/DSN-MUI/II/2018. Tentang: Layanan Pembiayaan Berbasis Teknologi Informasi Berdasarkan Prinsip Syariah.

Otoritas Jasa Keuangan (OJK). Statistik Perbankan Syariah Maret 2020.

Otoritas Jasa Keuangan (OJK). Statistik Fintech Lending Periode April 2020.

Otoritas Jasa Keuangan (OJK). POJK No.11/POJK.03/2020.

Undang-undang No. 20 tahun 2008 tentang Usaha Mikro, Kecil, dan Menengah. 